\title{
Financial Internationalization and Financial Security Issues
}

\author{
Ruyu Han \\ Department of Finance, Business School, Hohai University, Nanjing, China \\ Email: 15850681651@163.com
}

How to cite this paper: Han, R.Y. (2018) Financial Internationalization and Financial Security Issues. Open Access Library Journal, 5: e4874.

https://doi.org/10.4236/oalib.1104874

Received: August 29, 2018

Accepted: September 10, 2018

Published: September 13, 2018

Copyright (๑) 2018 by author and Open Access Library Inc.

This work is licensed under the Creative Commons Attribution International License (CC BY 4.0).

http://creativecommons.org/licenses/by/4.0/

\section{(c) () Open Access}

\begin{abstract}
Since 1980, financial globalization has gradually become the main theme in the international financial field. But at the same time, financial security issues have followed. So far, there have been many serious financial crises in the world, impacting the world's financial and economic systems. However, in contrast to China, there has never been a financial crisis in the process of promoting financial internationalization. The conclusions at home and abroad make us wonder: whether financial internationalization is a good or bad for a country's finances, and if there is no financial openness, there is no financial security problem. Therefore, this article will explore the general relationship between financial internationalization and financial security from the five dimensions of international finance. And it gives corresponding suggestions to China in the process of promoting financial internationalization.
\end{abstract}

\section{Subject Areas}

Economics

\section{Keywords}

Financial Internationalization, Financial Security, Financial Risk

\section{Introduction}

Financial internationalization refers to the state and process of the financial activity entity of an economy participating in the financial activities of another economy across administrative divisions, or vice versa, the core of which is "the process and state of financial integration in the world". The main performance dimensions are capital movements, financial institutions, business, markets, regulation and the internationalization of currencies. Financial security is often intertwined with financial internationalization and is closely related to financial 
sovereignty.

Since 1980, the wave of financial internationalization has swept the world. With the globalization of finance becoming the main theme of the international financial field, there have been many financial crises in the world. The continuous crisis in 1980, the Latin American debt crisis, the 1990 Asian financial crisis, and the 2010 US subprime mortgage crisis hit the world's financial and economic systems. However, in contrast to China, since the accession to the WTO in 2001, the process of financial internationalization has been greatly accelerated, but the financial crisis has never erupted. The financial industry has increased its development speed due to opening up. This makes us wonder why the relationship between financial internationalization and financial security is exactly what it is. In the future, China will be able to reduce financial risks and maintain financial security in the process of promoting internationalization.

In the following, we will proceed from the four dimensions of international finance, and point out in general terms the major financial security risks and problems that a country may have under each dimension, and analyze the path of each dimension that jeopardizes financial security, with a view to summarizing the general relationship between financial internationalization and financial security [1].

\section{Financial Internationalization and Financial Security}

\subsection{Capital Movement Internationalization and Financial Security}

The internationalization of the capital movement leads to uncertainty in the direction and scale of capital flows, which is a major hidden danger to the stability of a country's financial system. The internationalization of the capital movement provides a good institutional environment for the free entry and exit of capital. This not only makes the transnational transfer of financial assets and currency substitution more convenient, but also increases the probability that a country's financial system will be attacked by international hot money. At the same time, the excessive inflow of foreign capital will break the originally balanced supply and demand of funds in a country's financial market, fueling the expansion of the asset price bubble and seriously distort the country's financial and economic structure. In addition, short-term speculative capital flowing into the country will quickly return in the event of a reversal of the economic situation in the country or a worsening market expectation. This sensitive signal of capital flow is highly likely to cause financial panic in the domestic market, thus triggering capital flight. Under the influence of the "herd effect", the country's financial market will quickly fall into a liquidity dilemma.

\subsection{Financial Market Internationalization and Financial Security [2]}

The internationalization of a country's financial market is mainly reflected in the integrated development of domestic and international financial markets. The 
overseas listing of state-owned enterprises affects the financial security of a country. The large number of domestic high-quality enterprises listed overseas may lead to excessive internationalization of state-owned enterprises and adversely affect national interests and financial security. For foreign exchange control countries, the overseas listing of domestic-funded enterprises to raise foreign exchange funds will also cause a passive increase in domestic money supply, leading to a decline in the abnormality of market interest rates, thereby breaking the equilibrium of the domestic money market and affecting the stability of the country's financial industry. Moreover, with the improvement of the integration of domestic financial markets and international financial markets, a government can easily balance its balance of payments with the surplus of capital projects by borrowing foreign debts in the face of current account deficits. However, long-term borrowing of foreign debts will accumulate huge external debt risks for the domestic economy, and it is easy to induce a debt crisis. At the same time, the promotion of the integration of domestic and foreign financial markets has strengthened the linkage effect of financial markets in various countries. The bad news of overseas financial markets will quickly spread to the domestic financial market, directly reflected in the price fluctuations of financial investment products. In the emerging market economies, due to the serious information distortion and asymmetry of the market, the negative impact of bad news is often magnified, and even induces the turmoil in the domestic financial market.

\subsection{Financial Regulation Internationalization and Financial Security}

In the context of internationalization of financial regulation, there are many hidden concerns about financial security. The internationalization of finance has intensified the complexity of supervision, which is a severe test for a country's financial supervision ability. First of all, the diversification of financial instruments and the cross-cutting of business brought about by financial internationalization are likely to cause a regulatory vacuum for the traditional institutional supervision system. At the same time, the internationalization of financial markets provides favorable conditions for international speculative capital to attack the financial market of a country from the "multi-angle" of foreign exchange, securities and money markets, which greatly increases the difficulty of pre-regulatory and post-intervention by the regulatory authorities. Moreover, there is a conflict between institutional differences in financial supervision and regulatory international cooperation. Since international hot money always flows to countries and regions where financial supervision system is relatively weak, the objective existence of differences in financial supervision systems in various countries provides a space for "regulatory arbitrage" for international hot money. International experience shows that it is difficult for individual countries or regions to effectively monitor cross-border financial activities, and international cooperation in financial regulation must be strengthened. This places high demands on 
the ability of national regulatory authorities to act in concert.

\subsection{Financial Institutions Internationalization and Financial Security}

The internationalization of financial institutions mainly includes two aspects: "walking in" and "going out" of domestic financial institutions for international operation. On the one hand, the presence of foreign financial institutions may enhance the fragility of a country's financial system. In the enthusiasm for the introduction of strategic investors, if the domestic financial institutions are unable to judge the situation, they will consider the methods and consequences of the investment, and the hasty decision to attract investment will not only achieve the intended purpose of improving the corporate governance structure, but will easily lead to the outflow of wealth due to the dispersion of equity. The loss of business autonomy jeopardizes the financial security of a country. At the same time, the entry of foreign financial institutions weakens the effectiveness of monetary policy. On the other hand, once a domestic financial institution goes abroad, it puts itself in a highly uncertain business environment. Today's internationally complex political, economic and military situation has forced domestic financial institutions that set up branches abroad to face and bear the operational risks brought about by external environmental turmoil.

\section{Countermeasures to Deal with International Financial Risks}

Financial internationalization has brought opportunities to China's financial industry and economic development, and it has also brought about no small impact and problems that need to be seriously solved. As China's financial internationalization deepens, its challenges and tests will become more severe. In advancing the process of financial internationalization, China must proceed from its own reality, fully absorb foreign experience and lessons, and adhere to the principle of activeness and stability. It should formulate and implement correct strategies and strategies to avoid disadvantages, reduce or avoid the impact of international finance, and ensure financial security [3].

1) Implement a gradual financial internationalization strategy and steadily promote financial liberalization and financial market opening.

With the development of reform and opening up, China has liberalized some financial markets and successfully achieved exchange rate consolidation. In December 1996, the convertibility under the RMB current account was realized, and a key step in financial internationalization was taken. With the acceleration of China's opening up to the outside world and the continuous improvement of the degree of economic globalization, it will inevitably require further liberalization of finance and full opening of financial markets. Since the capital market, especially the securities market, is the main target of international speculative capital shocks, and China's capital market is lagging behind, the corresponding 
financial macro-control and guidance mechanisms have not yet been established. Therefore, we must actively and steadily and prudently and step by step to promote financial liberalization and capital market opening in accordance with the competitiveness of domestic financial institutions and the maturity of financial markets to avoid international financial risks.

2) Establish a complete financial management and regulatory system [4].

China's financial supervision system is imperfect, its supervision is not strict, and its effectiveness is lacking. To a certain extent, it has contributed to the emergence and increase of financial risks. Financial security has become a prominent problem in China's economic life. Therefore, we must take the establishment and improvement of financial supervision system and strengthen financial supervision as the top priority of financial reform. We must strengthen the central bank's supervision of finance in accordance with the requirements of the market economy, and improve the prevention mechanism, decentralization mechanism and compensation mechanism for financial risks. Drawing on foreign experience, we will establish China's financial early warning system and deposit insurance system to accelerate the legal construction of financial supervision. In view of the current imbalance in the development of the financial market structure, the Party Central Committee should improve the financial supervision system as soon as possible and strengthen the construction of relevant laws and regulations. And gradually replace the rule of the people with the rule of law, and we must truly have laws to follow, laws to follow, law enforcement to be strict, and violations of law.

3) Strengthen international cooperation and coordination, promote the reform and improvement of the international financial system and the international financial system.

At present, the international financial system and the international financial system are seriously unsuited to the needs of financial internationalization. In the prevention and resolution of the international financial crisis, there is no corresponding security and stability mechanism and effective means. Therefore, international cooperation and coordination has become a major channel for resolving the international financial crisis. Therefore, China should further strengthen international cooperation and coordination and make due contributions to the stabilization of international finance. At the same time, we should actively advocate and promote international financial reform, establish and improve the international financial system and international financial system that are compatible with the internationalization of financial development, and create an institutional basis and mechanism guarantee for resolving and preventing international financial risks.

4) Standardize the development of capital markets and steadily increase the proportion of direct financing.

Compared with major international countries, the financing channels of Chinese enterprises are relatively narrow, and credit risks are excessively concentrated 
in banks. Therefore, it is necessary to accelerate development and deepen the capital market, broaden the financing channels of enterprises, and establish complete capital market operation rules as soon as possible to expand The size of the capital market circulation increases the number and quantity of listed products. At the same time, it is necessary to improve the ability of investors to resist market risks and enhance the market's ability to restore liquidity, thereby promoting the diversification of asset structure and investment entities in the Chinese economic system, thereby realizing the transfer of risk subjects and risk structures. Make the cumulative risk of bad debts of institutional banks into institutional capital market risks. It cannot be ignored that due to the initial conditions of the initial development of the stock market, China's stock market has long had institutional defects, such as the defects of the listing system (implementation of the approval system, later changed to the approval system), and the delisting system is imperfect. Etc., resulting in distortion of capital market behavior, blocked information channels, unable to achieve effective reflection and transmission of information, and weakened the ability of the internal allocation of securities market resources. Therefore, we should improve the institutionalization of the securities market as soon as possible, and build a positive and stable development of the capital market.

\section{Conclusion}

Financial internationalization has become an irreversible trend and feature of world financial development. If China wants to develop, it must devote itself to the wave of financial internationalization and exchange the smallest financial security costs for the greatest financial benefits. Therefore, China should further strengthen international exchanges and cooperation, promote the reform and improvement of the international financial system and the international financial system, standardize the capital market, implement a gradual financial internationalization strategy, and steadily promote financial freedom by establishing a complete financial management and supervision system, to avoid the risks of financial internationalization and strengthen financial security.

\section{Conflicts of Interest}

The authors declare no conflicts of interest regarding the publication of this paper.

\section{References}

[1] Wu, T.T. (2011) Financial Internationalization and Financial Security-Theory and Evidence. Southwestern University of Finance and Economics, Chengdu, 20-37.

[2] Wang, Y.J. and Wu, T.T. (2013) Financial Internationalization and Financial Security Issues. University Theoretical Frontiers, 1, 34-36.

[3] He, J.W. and Yan, X. (2008) Analysis of the Financial Security Issues Faced by China's Financial Internationalization. China Business, 5, 31.

[4] Wang, W.J. (2016) China's Existing Financial Risk and Response Policy. Times Finance, 32, 22. 